\title{
Ejaculate Characteristics of Rabbits Infected with Trypanosoma congolense and Changes Caused after Treatment with Diminazene aceturate (Diminaveto®)
}

\author{
Características Eyaculatorias de Conejos Infectados con Trypanosoma congolense y \\ Cambios Causados después del Tratamiento con Diminazeno aceturato (Diminaveto®)
}

\author{
Olufisayo Oluwadamilare Leigh \& Oluremi Eric Fayemi
}

LEIGH, O. O. \& FAYEMI, O. E. Ejaculate characteristics of rabbits infected with Trypanosoma congolense and changes caused after treatment with Diminazene aceturate (Diminaveto®). Int. J. Morphol., 28(2):471-475, 2010.

SUMMARY: The effects of experimental Trypanosoma congolense infection on the ejaculate of rabbits and changes caused after treatment with Diminaveto ${ }^{\circledR}$ were investigated using 24 New Zealand White rabbits (bucks). The bucks were housed singly in standard rabbit cages and fed on specialized ration containing 10\% Protein supplement, grains, legume, salt and fresh water ad libitum during the study. Data on ejaculate characteristics were collected from all the bucks in the first phase (i.e. before infection) and in the second phase (i.e. during infection, with $4.8 \times 10^{5}$ Trypanosoma congolense, intraperitoneally). Similar data were collected from 12 randomly selected bucks treated with $7.0 \mathrm{mg} / \mathrm{kg}$ Diminaveto® following reconstitution during the third phase. Data collected were analysed using the Paired T- Test and Analysis of Variance. The infection led to significant $(\mathrm{P}<0.05)$ reduction in spermatozoa motility, concentration and mass activity, with a significant $(\mathrm{P}<0.05)$ increase in percentage of sperm cells with morphological abnormalities. Treatment with Diminaveto ${ }^{\circledR}$ led to improvement in all ejaculate parameters investigated. However, it was observed that the ejaculate did not attain the "before-infection" status following treatment with Diminaveto®. The study showed that infection with Trypanosoma congolense in rabbits caused significant reduction in ejaculate characteristics. Treatment with Diminaveto® however led to improvement in the ejaculate though at a rate slower than that at which the infection caused the reduction.

KEY WORDS: Ejaculate; Bucks; Trypanosoma congolense; treatment; Diminazene.

\section{INTRODUCTION}

African animal Trypanosomiasis has been reported as the most important of all animal diseases in Africa (Gasser, 1963). The disease has been recognized as the greatest constraint to agricultural development and the growth of livestock in Tropical Africa (WHO, 2001). About forty Countries in Africa are affected by the disease, where it has contributed to gross reduction of animal protein available to man (Sekoni, 1994). Similarly, several reproductive pathologies have been reported in association with Trypanosomiasis in both man and animals. They include irregular oestrus, sterility, intrauterine infections and abortions in the female (Apted, 1970; Ikede \& Losos, 1972; Reincke et al., 1998) and also, testicular degeneration, aspermatogenesis and various sperm abnormalities in the male (Anosa \& Isoun, 1980; Akpavie et al., 1986). It has also been observed that following treatment (i.e. chemotherapy) of infected animals, regeneration of seminiferous epithelium occurred at a rate which depended on the severity of initial lesions (Ikede \& Akpavie, 1982). Much of the studies however have been conducted using either Trypanosoma vivax or Trypanosoma brucei and frequently in the rat, cattle, sheep and goat. Since the rabbit is a non traditional meat source in many homes and its husbandry is becoming increasingly important for various reasons including its low venture starting capital and high multiplication rate, the present study was designed to investigate the effects of Trypanosome infection on ejaculate characteristics of rabbits infected with Trypanosoma congolense and their response to treatment with Diminazene aceturate. 


\section{MATERIAL AND METHOD}

Twenty four (24) New Zealand White rabbits (bucks) between the ages of 7 and 12 months were purchased from a reputable breeder within the University of Ibadan for the study. The bucks were housed singly in standard rabbit cages within the Laboratory Animal house of the Faculty of Veterinary Medicine, University of Ibadan. They were fed on specialized ration consisting of Protein supplement (i.e. groundnut and soyabean)-10\%; Grain (i.e. maize, sorghum, millet)- 49.5\%; Legume- $40 \%$ and Salt- $0.5 \%$. Fresh water was also provided ad libitum throughout the study. The bucks were allowed to stabilize for a week during which routine health checks were carried out through evaluation of rectal temperature $\left({ }^{\circ} \mathrm{F}\right)$, Heart rate $(/ \mathrm{min})$ and Packed cell volume (\%).

The modified A-V was made with two re-inforced rubber casings of different diameters between $3-4 \mathrm{cms}$ long. The two plastic casings were coupled together by inserting the one with lesser diameter into the other and fixing with the aid of an adhesive. A thin piece of disposable surgical glove (latex) served as inner lining which was folded backwards at both ends of the casings. Prior to the backward folding of the latex, 3-5ml of Diethylene glycol was introduced into the space between the coupled plastic casings and the latex to serve as lubricant (Hafez, 1970).

The bucks were trained twice daily within two weeks to ejaculate into the modified Artificial Vagina (A-V) (Fig. 1). The coupled $\mathrm{A}-\mathrm{V}$ was immersed in water at $70^{\circ} \mathrm{C}$ for about 5 minutes and removed to affix a small collecting tube

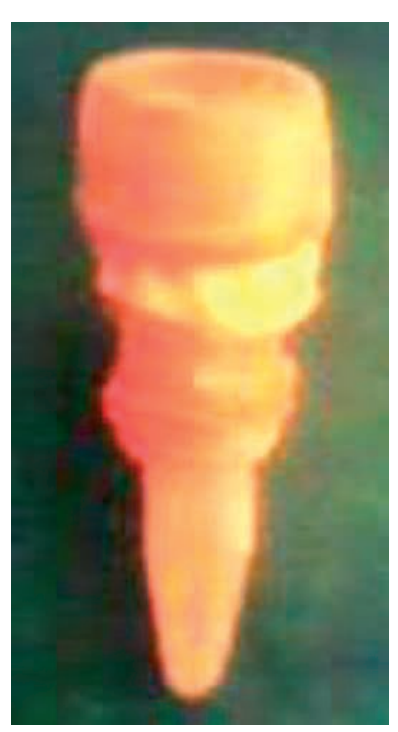

Fig. 1. Modified artificial vagina $(\mathrm{A}-\mathrm{V})$ used in the study. and semen volume were evaluated in the study using standard methods described by Zemjanis (1970). Primary (i.e. abnormal head and abnormal midpiece) and Secondary (i.e. bent and coiled tails, detached head) spermatozoa abnormalities were evaluated according to Bloom (1950).

The study was divided into 3 phases. In the first phase, ejaculate was collected before infecting the bucks with trypanosome and values of parameters were recorded. At the beginning of the second phase, the bucks were infected intraperitoneally with $4.8 \times 10^{5}$ Trypanosoma congolense (Kaura strain), which was collected through venopuncture from passaged albino rats and suspended in saline for immediate inoculation. Ejaculate was similarly collected and parameters were recorded. In the third phase, twelve randomly selected bucks were treated with $7.0 \mathrm{mg} / \mathrm{kg}$ bodyweight of Diminazene aceturate (Diminaveto ${ }^{\circledR}, \mathrm{VMD}$ Belgium) intramuscularly. The first, second and third phases lasted 4, 5 and 5 weeks respectively.

Data collected were analysed using the Paired T- Test and Analysis of Variance and the difference was regarded significant at $\mathrm{P}<0.05$ (Lewis, 1984).

\section{RESULTS}

Mean values of parameters monitored during the 1 week stabilization of the rabbits were as follows: Rectal temperature (99-102oF), Heart rate (181- 270/min) and Packed cell volume (40-42\%). These values showed that the rabbits used in the study were in good health. Table I shows the mean values for ejaculate parameters during the study. The spermatozoa motility decreased significantly $(\mathrm{P}<0.05)$ from $85.00 \pm 2.83$ (before infection) to $66.85 \pm 3.97$ (during infection) to $70.00 \pm 6.83$ during the 5 weeks following treatment with Diminaveto®. The spermatozoa concentration was also significantly $(\mathrm{P}<0.05)$ affected during the study. It decreased from a mean value of $72.70 \pm 12.56$ before infection to $48.70 \pm 3.97$ during infection and $68.50 \pm 3.25$ after diminaveto treatment. The changes in the mass activity was also significant $(\mathrm{P}<0.05)$. It reduced to $1.14 \pm 0.18$ during infection from a mean value of $2.00 \pm 0.17$ before infection and then $1.85 \pm 0.26$ after treatment with diminaveto. The sperm morphological abnormalities were similarly affected during the study. It increased significantly $(\mathrm{P}<0.05)$ from $17.38 \pm 0.71$ before infection to $29.96 \pm 3.24$ during infection and decreased to $20.75 \pm 1.00$ during the 5 weeks following treatment with diminaveto. The changes in the livability and semen volume were not significant $(\mathrm{P}>0.05)$. Table 2 shows weekly changes in ejaculate morphological characteristics during the study. During the 
Table I. Mean values of ejaculate parameters during the study.

\begin{tabular}{lcccc}
\hline Ejaculate parameter(s) & Before infection & During infection & $\begin{array}{l}\text { Following treatment } \\
\text { with Diminaveto }\end{array}$ & Significance \\
& (Phase 1) & (Phase 2) & (Phase 3) & \\
\hline Motility (\%) & $85.00 \pm 2.83$ & $66.85 \pm 3.97$ & $70.00 \pm 6.83$ & $\mathrm{P}<0.05$ \\
Concentration (x10 ${ }^{6}$ cells/m1) & $72.70 \pm 12.56$ & $48.70 \pm 3.97$ & $68.50 \pm 3.25$ & $\mathrm{P}<0.05$ \\
Livability (\%) & $77.50 \pm 4.55$ & $71.59 \pm 4.97$ & $74.50 \pm 3.10$ & $\mathrm{P}>0.05$ \\
Mass activity & $2.00 \pm 0.17$ & $1.14 \pm 0.18$ & $1.85 \pm 0.26$ & $\mathrm{P}<0.05$ \\
Morphological abnormalities (\%) & $17.38 \pm 0.71$ & $29.96 \pm 3.24$ & $20.75 \pm 1.00$ & $\mathrm{P}<0.05$ \\
Volume (mls) & $0.58 \pm 0.10$ & $0.76 \pm 0.07$ & $0.61 \pm 0.06$ & $\mathrm{P}>0.05$ \\
\hline
\end{tabular}

Table II. Mean weekly percentage morphological characteristics of ejaculate during the study.

\begin{tabular}{|c|c|c|c|c|c|c|}
\hline Week (s) & $\begin{array}{l}\text { Normal } \\
\text { spermatozoa (\%) }\end{array}$ & $\begin{array}{l}\text { Abnormal } \\
\text { head } \\
(\%)\end{array}$ & $\begin{array}{l}\text { Abnormal } \\
\text { midpiece }(\%)\end{array}$ & $\begin{array}{l}\text { Bent tail } \\
(\%)\end{array}$ & $\begin{array}{l}\text { Coiled tail } \\
(\%)\end{array}$ & $\begin{array}{l}\text { Detached } \\
\text { head } \\
(\%)\end{array}$ \\
\hline Before infection & 71.00 & 3.50 & 2.45 & 10.70 & 6.85 & 5.50 \\
\hline 2 & 72.00 & 3.80 & 2.25 & 9.50 & 5.00 & 7.45 \\
\hline 3 & 75.00 & 4.00 & 2.50 & 9.00 & 4.50 & 5.00 \\
\hline 4 & 74.50 & 3.90 & 2.70 & 8.90 & 5.00 & 5.00 \\
\hline Infection & 72.20 & 3.85 & 2.55 & 9.50 & 5.80 & 6.10 \\
\hline 6 & 71.00 & 4.20 & 3.20 & 9.45 & 5.75 & 6.40 \\
\hline 7 & 69.80 & 7.50 & 4.15 & 9.70 & 4.85 & 4.00 \\
\hline 8 & 66.00 & 10.50 & 7.80 & 9.45 & 2.20 & 4.05 \\
\hline 9 & 60.00 & 12.30 & 7.95 & 10.05 & 5.70 & 4.00 \\
\hline Diminaveto $\quad 10$ & 52.20 & 16.85 & 9.50 & 11.45 & 5.70 & 4.30 \\
\hline 11 & 49.50 & 17.20 & 10.00 & 12.00 & 7.80 & 3.50 \\
\hline 12 & 55.00 & 17.00 & 9.90 & 11.60 & 4.30 & 1.08 \\
\hline 13 & 59.70 & 15.20 & 9.20 & 11.05 & 3.85 & 1.00 \\
\hline 14 & 62.40 & 13.50 & 7.90 & 10.50 & 3.85 & 1.85 \\
\hline
\end{tabular}

4 weeks before infection, percentage normal spermatozoa ranged between $71.00 \%$ and $74.50 \%$. This value reduced significantly $(\mathrm{P}<0.05)$ to $52.20 \%$ during infection and rose to $62.40 \%$ during the 5 weeks following treatment with diminaveto. The changes in both percentages abnormal head and abnormal midpiece during the study were significant $(\mathrm{P}<0.05)$. The percentage abnormal head changed from $3.90 \%$ before infection to $16.85 \%$ during infection and $13.50 \%$ during the 5 weeks following diminaveto treatment. The percentage abnormal midpiece changed from $2.70 \%$ before infection to $9.50 \%$ during infection and $7.90 \%$ following diminaveto treatment. The changes in the percentage secondary abnormalities were not significant $(\mathrm{P}>0.05)$ except for detached heads which changed from $5.00 \%$ before infection to $4.30 \%$ during infection and $1.85 \%$ following diminaveto treatment.

\section{DISCUSSION}

The involvement of the reproductive system in both natural and experimental trypanosome infections have been reported in literature (Apted; Isoun \& Anosa, 1974; Ikede et al., 1988). In the present study, the spermatozoa motility, concentration and mass activity were significantly reduced, while morphological abnormalities of spermatozoa increased. These characteristics of the ejaculate are not only vital to the physiological functions of the spermatozoa which include spermatozoa migration and fertilization (Hunter, 1977) but are also considered in the evaluation of an animal for breeding soundness (Ott, 1986). This means that either or both natural and experimental Trypanosoma congolense infection of bucks will result in reduced spermatozoa 
migration and fertilization and also the rejection of such bucks as potential breeders. Spermatozoon is produced from the seminiferous tubule of the testis in a complex process known as spermatogenesis (Roosen-Runge, 1977). The process of spermatogenesis is under the control and influence of both the endocrine and certain external factors e.g. photoperiod and presence of noxious agents (Ortavant $e$ t al., 1977; MacDonald \& Pineda, 1989). Any affection e.g. invasion of the tissues involved in spermatogenesis by pathogens or other structures regulating the spermatogenic tissues will result in reduction of ejaculate qualities (White, 1933; Noakes et al., 2001). The observed reductions in ejaculate characteristics in this study (Table I) are similar to earlier reports (Akpavie et al.). Since Trypanosoma congolense possess the ability to invade tissue in certain circumstances (Adah et al., 1992), the observed reduction in ejaculate characteristics can be linked to the effects of the infection. This is more clearly elucidated by the weekly changes in spermatozoa morphology (Table II). Table II indicates a gradual increase in the percentage abnormalities for both abnormal heads and midpiece with a corresponding reduction in the percentage of normal spermatozoa. However, throughout the study, it was observed that following treatment with diminaveto, there were improvements in ejaculate characteristics. Only that in some of the cases, the ejaculate picture failed to return to the pre infection status except for the percentages of coiled tail and detached heads (which are secondary abnormalities occurring during spermatozoa storage and may not reflect any challenge or insult to spermatogenic tissues). This observation may have resulted because of the relatively short duration of the study after treatment with diminaveto (Ikede \& Akpavie). This finding agreed with earlier report that resolution of damage caused by trypanosome infection in the reproductive organs of rabbits required much longer than the duration of the infection (Ikede \& Akpavie; Ige \& Amodu, 1975). In the present study, the duration of ejaculate collection and evaluation during the $2^{\text {nd }}$ and $3^{\text {rd }}$ phases were the same. It is very likely that an extension by several weeks of the 3 rd phase (i.e. following diminaveto treatment) would have led to significant improvement and resolution within the spermatogenic tissues which could have reflected in enhancement of collected ejaculate properties without appreciable disparity to the pre infection period. A significant increase in primary sperm abnormalities was also observed between the $4^{\text {th }}$ and $5^{\text {th }}$ week following infection and continued until the $4^{\text {th }}$ and $5^{\text {th }}$ weeks following treatment with diminaveto. This finding indicates an equal length of time between the duration of infection and the onset of resolution once effective chemotherapy was instituted. The rate of resolution may however be slow to produce significant changes in the ejaculate, this requiring alonger period before becoming obvious. This observation is again similar to earlier report (Ikede \& Akpavie) and suggests similarity in the pathophysiology and pathogenecity with respect to ejaculate changes between $T$. brucei and T. congolense infection of rabbits. In conclusion, Trypanosoma congolense infection of rabbits caused significant reduction in ejaculate characteristics. However, treatment with diminaveto produced gradual improvement which was observed to require longer duration than the duration before the ejaculate can return to its initial status before infection.

LEIGH, O O. \& FAYEMI, O. E. Características eyaculatorias de conejos infectados con Trypanosoma congolense y cambios causados después del tratamiento con Diminazeno aceturato (Diminaveto®). Int. J. Morphol., 28(2):461-470, 2010.

RESUMEN: Fue estudiado en 24 conejos Nuevo zelandeses blancos, machos, los efectos de la infección experimental de Trypanosoma congolense sobre la eyaculación y los cambios producidos después del tratamiento con Diminavetoß . Los machos fueron colocados individualmente en jaulas de conejos estándar. Durante el estudio fueron alimentados con ración especializada, con $10 \%$ de suplemento de proteínas, granos, legumbres, sal y agua fresca ad libitum. Los datos sobre las características de la eyaculación se obtuvieron de todos los machos en la primera fase (es decir, antes de la infección) y en la segunda fase (es decir, durante la infección, con 4,8x $10^{5}$ Trypanosoma congolense, por vía intraperitoneal). Datos similares se obtuvieron de 12 machos al seleccionados al azar, tratados con Diminaveto ${ }^{\circledR} 7,0 \mathrm{mg} / \mathrm{kg}$ después de la reconstitución durante la tercera fase. Los datos fueron analizados mediante $t$ de student y análisis de varianza. La infección fue significativa $(\mathrm{P}<0,05)$ habiendo reducción de la motilidad de los espermatozoides, la concentración y actividad de masas, con un efecto significativo $(\mathrm{P}<0,05)$ aumento en el porcentaje de espermatozoides con anomalías morfológicas. El tratamiento con Diminaveto ${ }^{\circledR}$ condujo a una mejoría en todos los parámetros investigados del eyaculado. Sin embargo, se observó que el eyaculado no alcanzó el "antes de la infección" tras el tratamiento con Diminaveto®. Además, el estudio mostró que la infección con Trypanosoma congolense en conejos causó una reducción significativa en las características del eyaculado. Sin embargo, el tratamiento con Diminaveto ${ }^{\circledR}$ condujo a una mejoría en la eyaculación aunque a un ritmo más lento que en la infección causada por la reducción.

PALABRAS CLAVE: Ejaculación; Machos; Trypanosoma congolense; Tratamiento; Diminazeno. 


\section{REFERENCES}

Adah, M. I; Otesile, E. B \& Joshua, R. A. Changes in levels of transaminases in goats experimentally infected with $\mathrm{T}$ congolense. Revue Elev. Med. Vet. Pays Trop., 45(34):284-6, 1992.

Anosa, V. O. \& Isoun, T. T. Further observations on the testicular pathology in Trypanosoma vivax infection of sheep and goats. Res. Vet. Sci., 28:151-60, 1980.

Akpavie, S. O.; Ikede, B. O. \& Egbunike, G. N. Ejaculate characteristics of sheep infected with Trypanosoma brucei and T. vivax: changes caused by treatment with diminazene aceturate. Res. Vet. Sci., 42(1):1-6, 1986.

Apted, F. Clinical manifestations and diagnosis of sleeping sickness. In: Mulligan, H. W. (ed.). The African Trypanosomiases, London, Allen \& Unwin, 1970.

Bloom, E. Interpretation of spermatic cytology in bulls. Fert. Steril., 1:223-38, 1950.

Gasser, H. S. The bane of Tropical Africa. Lancet, 1:1091, 1963.

Hafez, E. S. E. Reproduction and Breeding Techniques for Laboratory Animals. 2.Ed. London, Lea \& Febiger, 1970.

Hunter, R. H. Physiological factors influencing ovulation, fertilization, early embryonic development and establishment of pregnancy in pigs. Br. Vet. J., 133:461-70, 1977.

Ige, K. \& Amodu, A. A. Report of the $14^{\text {th }}$ Meeting of the International Scientific Council for Trypanosomiasis Research and Control. Dakar, Senegal, 1975. pp. 151-6.

Ikede, B. O \& Akpavie, S. O. Delay in resolution of trypanosome-induced genital lesions in male rabbits infected with Trypanosoma brucei and treated with diminazene aceturate. Res. Vet. Sci., 32:374-6, 1982.

Ikede, B. O.; Elhassan, E. \& Akpavie, S. O. Reproductive disorders in African trypanosomiasis: a review. Acta Trop., 45(1):5-10, 1988.

Ikede, B. O \& Losos, G. J. Hereditary transmission of Trypanosoma vivax in sheep. Brit. Vet. J., 128(1):i-ii, 1972.

Isoun, T. T. \& Anosa, V. O. Lesions in the reproductive organs of sheep and goats infected with T. vivax. Z. Tropenmed. Parasit., 25:469-76, 1974.
McDonald, L. E \& Pineda, M. H. Veterinary Endocrinology and Reproduction. Philadelphia, Lea \& Febiger, 1989.

Noakes, D. E; Parkinson, T. J \& England, G. C. W. Arthur"s Veterinary Reproduction and Obstetrics. New York, Saunders, 2001.

Lewis, A. E. Biostatistics. 2. ed. New York, Van Nostrand Reinhold Co. Inc., 1984.

Ortavant, R.; Courot, M. \& de Reviers, H. Spermatogenesis in domestic mammals. In: Reproduction in domestic animals. London, Academic Press, 1977. pp. 223- 4.

Ott, R. S. Breeding soundness examination of bulls. In: Current Therapy in Theriogenology, Morrow, D.A. (ed.). Philadelphia, W.B. Saunders Co., 1986. pp. 125-36.

Reincke, M.; Arlt, W.; Heppner, C.; Petzke, F.; Chrousus, G. P. \& Allolio, B. Neuroendocrine dysfunction in African trypanosomiasis. The role of cytokines. Ann. $N$ Y Acad. Sci., 840:809-21, 1998.

Roosen-Runge, E. C. The process of spermatogenesis in animals. London, Cambridge University Press, 1977. pp.1- 12 .

Sekoni, V. O. Reproductive disorders caused by animal trypanosomiases: a review. Theriogenology, 42(4):55770,1994

White, W. E. Duration of fertility and the histological changes in the reproductive organs after ligation of the vasa efferentia in the rat. Proc. Roy. Soc. (London), B113:54450, 1933.

WHO. Tropical diseases database. 2001. Avaible in: http:// www-nt.who.int./imagelib.pl

Zemjanis, R. Diagnostic and Therapeutic Techniques in Animal Reproduction. 2.ed. Baltimore, Williams \& Wilkins, 1970.

Correspondence to:

Dr O.O Leigh

Department of Veterinary Surgery and Reproduction, University of Ibadan

NIGERIA

Received: 04-07-2009

Accepted: 04-11-2009

Email: damilareolufisayo@yahoo.com 
